\title{
Administrative Monopoly in China
}

Causes, Behaviors, and Termination 


\section{Series on Chinese Economics Research}

(ISSN: 2251-1644)

Series Editors: Yang Mu (Lee Kuan Yew School of Public Policies, NUS)

Fan Gang (Peking University, China)

Published:

Vol. 1: China's State-Owned Enterprises: Nature, Performance and Reform by Sheng Hong and Zhao Nong

Vol. 2: Food Security and Farm Land Protection in China by Mao Yushi, Zhao Nong and Yang Xiaojing

Vol. 3: The Micro-Analysis of Regional Economy in China:

A Perspective of Firm Relocation by Wei Houkai, Wang Yeqiang and Bai Mei

Vol. 4: The China Dream and the China Path by Zhou Tianyong

Vol. 5: Beyond Demographic Dividends by Cai Fang

Vol. 6: People's Livelihood in Contemporary China:

Changes, Challenges and Prospects edited by Li Peilin

Vol. 7: New Paradigm for Interpreting the Chinese Economy:

Theories, Challenges and Opportunities

by Justin Lin Yifu

Vol. 8: Economic Transition in China:

Long-Run Growth and Short-Run Fluctuations by Yuan Zhigang

Vol. 9: Opening Up China’s Markets of Crude Oil and Petroleum Products: Theoretical Research and Reform Solutions by Hong Seng and Pu Qian

Vol. 10: Administrative Monopoly in China: Causes, Behaviors and Termination by Sheng Hong, Zhao Nong and Yang Junfeng 


\title{
Administrative Monopoly in China \\ Causes, Behaviors, and Termination
}

\author{
SHENG Hong \\ The Unirule Institute of Economics, China \\ \& Shandong University, China \\ ZHAO Nong \\ The Unirule Institute of Economics, China \\ \& The Institute of Economics in CASS, China \\ YANG Junfeng \\ The Unirule Institute of Economics, China \\ \& Law School of PPSUC, China
}




\section{Published by}

World Scientific Publishing Co. Pte. Ltd.

5 Toh Tuck Link, Singapore 596224

USA office: 27 Warren Street, Suite 401-402, Hackensack, NJ 07601

UK office: 57 Shelton Street, Covent Garden, London WC2H 9HE

\section{Library of Congress Cataloging-in-Publication Data}

Sheng, Hong, 1954-

Administrative monopoly in China : causes, behaviors and termination / by Sheng Hong,

Zhao Nong \& Yang Junfeng.

pages cm. -- (Series on Chinese economics research, ISSN 2251-1644; vol. 10)

Includes bibliographical references and index.

ISBN 978-9814611060 (alk. paper)

1. Government ownership--China. 2. Monopolies--China. 3. Government business enterprises-China. I. Title.

HD4318.S53467 2015

338.6'20951--dc23

2014033598

\section{British Library Cataloguing-in-Publication Data}

A catalogue record for this book is available from the British Library.

Copyright (C) 2015 by World Scientific Publishing Co. Pte. Ltd.

All rights reserved. This book, or parts thereof, may not be reproduced in any form or by any means, electronic or mechanical, including photocopying, recording or any information storage and retrieval system now known or to be invented, without written permission from the publisher.

For photocopying of material in this volume, please pay a copying fee through the Copyright Clearance Center, Inc., 222 Rosewood Drive, Danvers, MA 01923, USA. In this case permission to photocopy is not required from the publisher.

In-house Editors: Dong Lixi/Sree Meenakshi Sajani

Typeset by Stallion Press

Email: enquiries@stallionpress.com

Printed in Singapore 


\section{Contents}

Abstract $\quad$ xxi

Introduction xxiii

Chapter 1 Nature of Administrative Monopolies 1

1. Definition of Administrative Monopoly 1

2. Composition of Administrative Monopoly 2

2.1. Use of public powers mainly by administrative departments 2

2.2. Establishment of monopoly status 3

2.3. The main actor in administrative monopoly 4

3. Administrative Monopolies vs. Market Monopolies 4

3.1. Formation of the monopoly 5

3.2. Use of public power 5

3.3. Potential competition 5

4. Constitutional Characteristics of Administrative Monopoly 6

5. Main Forms of Administrative Monopoly 8

5.1. Establishment of barriers to entry 8

5.2. Price regulations on products sold by the monopolist 9

5.3. Preferential prices on input purchases 9

5.4. Promotion of mergers leading to monopolies 10

5.5. Barriers on the movement of products and resources
between regions 
Chapter 2 Formation and Cause of Administrative Monopolies 11

1. Formation and Evolution of Administrative Monopolies 11

1.1. Formation and evolution of administrative monopolies in the telecom industry 11

1.2. Formation and evolution of administrative monopolies in the oil industry

1.3. Formation and evolution of administrative monopolies in the banking industry

1.4. Formation and evolution of administrative monopolies in the table salt industry

2. The Inertia of the Planned Economy 18

3. Absence of Fiscal Pressure on Central Government for Reform 19

4. The Market Value of Administrative Monopolies and the Formation of Self-Aware Monopoly Interest Groups 20

5. In-House Lobbying 23

6. "Departmental Legislation” 26

\section{Chapter 3 Pervasiveness of Administrative Monopolies 31}

1. Allocation of Administrative Monopolies in Industries 31

2. Administrative Monopolies in the Telecommunications Industry 33

2.1. Designated operators 33

2.2. Entrance thresholds $\quad 34$

2.3. Price regulations $\quad 35$

2.4. Market structure in broadband 36

2.5. Market structure for mobile phones and fixed lines $\quad 37$

3. Administrative Monopoly in the Oil Industry 38

3.1. Legal status of administrative monopoly 38

3.1.1. Administrative monopoly in the upstream extraction process 38

3.1.2. Administrative monopolies in the mid-stream refinery process 40

3.1.3. Administrative monopolies in wholesale refined oil

3.1.4. Administrative monopolies in the supply and delivery process 
3.1.5. Administrative monopolies in the importing of crude oil

3.1.6. Administrative monopoly in oil reserves

3.2. Market structure

4. Administrative Monopoly in the Railway Industry 42

5. Administrative Monopoly in the Banking Industry 44

5.1. Interest rate regulations 45

5.2. Market structure 45

6. Administrative Monopoly in the Salt Industry 46

6.1. Legal status of administrative monopoly in the salt industry $\quad 46$

6.2. Monopoly structure of the table salt industry 48

6.3. Monopoly prices in the table salt industry 48

7. Administrative Monopoly in the Football Industry 49

7.1. Exclusive status of sports associations 49

7.2. Powers of sport associations $\quad 50$

7.2.1. Decisions over eligibility 50

7.2.2. Discipline and punishment 50

7.2.3. Management and organization of competitions $\quad 50$

7.2.4. Ownership and usufruct of leagues $\quad 50$

8. Administrative Monopolies in Localities 51

\section{Chapter 4 Illegality of Administrative Monopolies 53}

1. Lack of Legal Authorization and Violation of the Principle of Legal Reservation 53

1.1. Authorization with only administrative documents $\quad 54$

1.2. Overreach of authorization from lower-level documents 56

1.3. Unclear and abnormally high entrance requirements specified by laws

1.3.1. Stipulations too vague, providing too much discretionary power

1.3.2. Excessively high entrance requirements 61

1.3.3. Laws inappropriate and unconstitutional 


\section{Chapter 5 Administrative Monopoly Behaviors}

1. Classification of Administrative Monopoly Behaviors 65

1.1. Action by administrative departments to create administrative monopolies

1.2. Administrative monopoly behaviors by enterprises 66

1.3. Individual behaviors caused by administrative monopoly 67

2. Examples of Administrative Monopoly Behavior in Departments

2.1. Setting institutional barriers to entry

2.2. Creating direct price regulations or product pricings that are beneficial to administrative monopoly enterprises

2.3. Leading and pushing mergers in order to increase the centralization of industries

2.4. Offering preferential policies in areas such as taxation, lands, fees for utilizing natural resources, and profit remittances to large-scale SOEs such as central SOEs

2.5. Offering aid to monopoly enterprises through refinancing, asset restructuring, and debt divestitures

2.6. Offering enterprises import monopoly concessions for resources (such as crude oil, iron ores, etc.)

2.7. Granting administrative monopoly status in transportation

2.8. Violating the Price Law by not holding hearings for the determination or adjustment of prices, or holding hearings with obvious procedural flaws

2.9. Offering enterprises portions of administrative powers

3. Examples of the Administrative Monopoly Behaviors by Enterprises

3.1. Setting high prices or influencing the setting of prices for products or services (including long-distance calls, broadband, and gasoline), or implementing price discrimination

3.2. Controlling the sales network or channels of products

3.3. Implementing unfair competition or sales practices such as bundle sales or cross-subsidization 
3.4. Implementing unfair competition by cross-subsidization, and cheating the government out of subsidies

3.5. Conspiring to create price cartels with other monopolists, often in the name of self-regulation

3.6. Extending the monopoly in one production stage to its upstream and downstream stages to gain preferential conditions there as well

4. Examples of Individual or Organizational Behaviors Caused by Administrative Monopolies

4.1. Direct benefits from the power over establishing administrative monopolies, such as bribery

4.2. Gaining a portion of monopoly rents through advantageous purchase prices for or from one's own enterprise

4.3. Using the shortage caused by the administrative monopoly to monopolize the sales of parts of the products, profiting from abnormally high prices

Chapter 6 Inefficiency and Unfairness of Administrative Monopoly

1. Inefficiency and Unfairness of Setting Barriers to Entry 85

1.1. Administrative monopoly model for barriers to entry 85

1.2. Reasonable institutional barriers to entry 88

2. The Inefficiency and Unfairness of Regulation of Sales Prices

3. Purchase-Price Regulation: Resources Sold at Low Prices or Given away for Free

4. Affecting the Neutrality of Macroeconomic Policies

4.1. The distribution distortion brought by administrative monopolies generates inflation

4.2. Tendency to adopt expansionary fiscal policies

4.3. Monetary policy favors adjusting deposit reserve requirements rather than interest rates

5. Damage to Social Justice

6. Damage to Political Legitimacy and Moral Values 


\section{Chapter 7 Estimation of Welfare Loss and Distribution} Distortions Caused by Administrative Monopolies

1. Measuring Methods of Welfare Loss and Distribution

Distortions Caused by Administrative Monopolies

1.1. Several aspects of net social welfare losses and distribution distortions

1.2. Approximation method of social welfare losses: The Harberger triangle

1.3. Approximation method of distribution distortions and social welfare losses caused by regulations on sales prices for monopolists

1.4. Approximation method of distribution distortions and social welfare losses caused by regulated purchase prices for monopolists

1.5. Different kinds of social welfare losses

1.6. Approximation method of resource allocation losses $\quad 104$

1.7. Methods for a quantitative approximation of the inflation effect of administrative monopolies

1.8. Methods for approximating income transfers resulting from adjustments to reserve requirements instead of interest rates

2. Estimation of Welfare Loss and Distribution Distortions Caused by Administrative Monopolies

2.1. Estimation of the social welfare loss I (narrow-bore) 109

2.1.1. Telecommunications industry

2.1.2. Oil industry

2.2. Estimation of social welfare loss II (monopoly profits) 110

2.2.1. Telecommunications industry 110

2.2.2. Oil industry 110

2.2.3. Table salt industry 111

2.3. Estimation of the social welfare loss III (losses for resource owners)

2.3.1. Petroleum industry

2.3.2. The banking industry

2.3.3. The approximation of loss from misallocation of resources 
2.3.4. The inflation effect of administrative monopolies 116

2.3.5. Distribution distortion and welfare losses from adjusting reserve requirements instead of interest rates

2.3.6. Summation of social welfare losses in the industries studied

3. Real Performance and Income Distribution of Administrative Monopolists

3.1. Real performance 119

3.1.1. Telecommunications industry 119

3.1.2. Petroleum industry 119

3.1.3. Banking industry 120

3.2. Income distribution $\quad 120$

3.2.1. Telecommunications industry 120

3.2.2. Petroleum industry

\section{Chapter 8 Breaking Administrative Monopoly 125}

1. Existing Anti-Monopoly Laws

2. The Constitutional Level: Restricting and Forbidding Departmental Legislation

3. The Constitutional Level: Effective Control of the State Economy and SOEs

4. Utilizing Existing Constitutional and Legal Resources, Clearing Out Documents Establishing Administrative Monopolies

5. Toward a Legal and Judicial Anti-Monopoly System 136

6. Breaking Administrative Monopoly by Administrative Means 141

\section{Sub-Report 1: Administrative Monopoly} in the Telecommunications Industry

1. History of Administrative Monopoly in the Telecommunications Industry

1.1. The Ministry of Posts and Telecommunications: Administrator, enterprise and monopolist (1979-1994) 
1.2. China Unicom formed, administrative monopoly by the "Big Two" in the telecom market (1994-1998) 146

1.3. Obstacles to competition under the management of the Ministry of the Information Industry (Later renamed the Ministry of Industry and Information Technology) (1998-present)

2. Legal Status of Administrative Monopoly in the Telecommunications Industry

2.1. Designated operators

2.2. Entrance thresholds 151

2.3. Price regulations 152

3. Market Structure of the Telecom Industry 154

3.1. Broadband internet connection 154

3.2. Mobile market and fixed-line market $\quad 156$

3.3. A measure of barriers to entry 156

4. Behavior of Administrative Monopolists in the

Telecommunications Industry

4.1. Administrative departments setting up and maintaining administrative monopolies

4.1.1. Opposition to China Unicom's entry 157

4.1.2. Guiding the restructuring of enterprises 159

4.2. Profit behavior by enterprises using administrative monopoly

4.2.1. Discriminatory inter-network rates 160

4.2.2. Monopoly prices 162

4.2.3. Rent-seeking 163

4.3. Individual or institutional behaviors induced by administrative monopoly

4.3.1. Direct abuses of administrative power to grant monopolies

4.3.2. Corruption through front companies $\quad 165$

5. Social Welfare Losses 166

5.1. Net welfare losses for society 167

5.1.1. Estimation of the lower bound 167

5.1.2. Estimations of the upper bound 168 
5.2. Underestimated costs 168

5.2.1. Land rentals 168

5.2.2. Auction of telecom phone number resources 168

5.3. Welfare losses 171

5.4. Income distribution in administrative monopolies 171

5.4.1. Industry salary and benefits 171

5.4.2. Executive pay 174

6. Reasons for the Formation of Administrative Monopoly in the Telecom Industry

6.1. System-wide inertia

6.2. Reinforcement of monopoly by administrative authorities

6.3. Financial demands from the central government 176

6.4. In-house lobbying

\section{Sub-Report 2: Administrative Monopoly in the Oil Industry 179}

1. Market Structure of the Oil Industry 179

1.1. Proportion of state-owned assets 179

1.2. Market structure 179

2. Formation and Evolution of the Administrative Monopoly in the Oil Industry 180

3. Characteristics and Legal Status of Administrative Monopoly in the Oil Industry

3.1. Administrative monopoly in the upstream oil exploitation sector

3.1.1. Granting the Big Three their monopolies 184

3.1.2. Strict entry approval system 186

3.1.3. Support given to state-owned capital 187

3.2. Administrative monopoly in the midstream refining and chemical sector

3.3. Administrative monopoly in the downstream refined oil markets

3.4. Administrative monopoly in the supply and distribution sector

3.5. Administrative monopoly in the crude oil import sector 190

3.6. Administrative monopoly in the oil reserve sector 
4. Causes of Administrative Monopoly 192

4.1. Inertia of the planned economy 192

4.2. Ideological misconception 192

4.3. Maximization of the central government's fiscal revenue

4.4. In-house lobbying 195

5. Administrative Monopoly Behaviors 195

5.1. Administrative departments setting up and maintaining administrative monopolies

5.1.1. Expanding powers through departmental regulations

5.1.2. Consolidating monopoly positions through preferential policies

5.1.3. Adopting the pricing mechanism in favor of the monopoly enterprises

5.2. Profit seeking behaviors of enterprises through administrative monopoly

5.2.1. Controlling the sales channels

5.2.2. Squeezing the profit of private enterprises through cross-subsidization

5.2.3. Contending for favorable locations for gas stations

5.2.4. Eliminating competitors by administrative means

5.2.5. Using resource advantages to extend monopoly powers downstream

5.3. Rent-seeking behaviors of individuals

6. Welfare Loss and Distribution Distortion 205

6.1. Net social welfare loss 205

6.2. Understated cost 205

6.2.1. Underpayment of rent for industrial land 205

6.2.2. Underpayment of the rent on land for gas stations

6.2.3. Underpayment of resource rent 207

6.2.4. Government subsidies 209

6.2.5. Financing costs below market levels 209

6.2.6. Welfare loss caused by monopoly prices 210 
6.3. Welfare loss 213

6.4. Distribution 214

6.4.1. Wages 214

6.4.2. Executive compensation 215

6.4.3. Others 215

6.5. Summary 217

Appendices 217

Sub-Report 3: Administrative Monopoly in the Railway Industry

1. Formation and Evolution of Administrative Monopoly in the Railway Industry $\quad 219$

2. Manifestation of the Administrative Monopoly 224

2.1. Barriers to entry 224

2.2. Price control 226

2.2.1. Price control for ordinary trains 226

2.2.2. Price control for high-speed railways 227

3. Efficiency Analysis of Railway Investment 229

3.1. Manifestation and causes of the investment deviation 229

3.2. Estimated social welfare loss caused by the misallocation of the railway resources

3.3. Logical errors in the large-scale investment in high-speed railway

4. Safety on High-speed Railways 240

4.1. The accident 241

4.2. Rescue operations following the accident 243

4.3. Handling of the accident 244

4.3.1. Responsible individuals 244

4.3.2. Responses to the accident 245

4.3.3. Speed and price reductions 246

4.4. Problems with the investigation report 247

5. Monopoly Behavior and Rent-Seeking 248

5.1. Monopoly behavior 248

5.1.1. Bundled sales 248

5.1.2. Railway passenger insurance 248 
5.2. Rent-seeking 252

5.2.1. Scalpers 253

5.2.2. Institutional rent-seekers 254

5.3. Unconstrained administrative power 256

5.3.1. A kingdom with its own judicial system 256

5.3.2. Lack of accountability in the system 257

5.3.3. Poor information transparency 258

6. Zhang Shuguang's Case: A Classic Case of Using

Monopoly Powers for Rent-Seeking Activities 260

$\begin{array}{ll}\text { Appendices } & 262\end{array}$

Sub-Report 4: Administrative Monopoly

in the Banking Industry

1. Status Quo of the Banking Industry in China 269

1.1. Overview of the banking industry 269

2. History of the Banking Industry in China and Formation of its Administrative Monopoly 270

2.1. Formation of the existing banking system in China 270

2.2. Interest rate system 272

2.3. Market access system 273

3. Manifestation of Administrative Monopoly in the

Banking Industry

3.1. Administrative department appointment of bank management

3.2. Problems of bank supervision bodies:

Inadequate effectiveness and independence

3.2.1. A look at the effectiveness and independence of financial supervision bodies, taking the China banking regulatory commission as an example

3.2.2. Establishment and dissolution of the financial work committee under the CPC central committee 
3.3. Government support to state-owned banks:

Picking up the bill on bad loans 278

3.4. Control over market entry in the banking industry 279

3.4.1. Evolution of private capital's entry into the banking industry 280

3.4.2. Institutional barriers to the private banking industry 281

3.4.3. Village banks and microcredit companies $\quad 282$

3.5. Interest rate control in the banking industry 284

3.6. Banks taking advantage of their monopoly position 286

4. Distribution Distortions and Welfare Loss Caused

by Interest Rate Control and Banking Monopoly 287

4.1. China's control over the interest spread and its impact on the balance sheets of banking institutions

4.2. Dual distortions from interest rate controls

5. Estimation of the Banking Industry's Actual Net Interest Income and the State-Owned Banks' Actual Performance

5.1. A calculation that gives a true view of the net interest income of China's banking industry

5.1.1. Nominal income from net interest in the banking industry in 2010

5.1.2. Actual net interest income of the banking industry in 2010

5.2. Efficiency of the banking industry under administrative monopoly

5.2.1. Efficiency gap between China's listed banks

5.2.2. Efficiency gap between the top 10 listed banks across the world

5.2.3. Actual performance of state-owned banks

6. Estimation of Distribution Distortion from Adjusting Reserve Requirements Rather than Interest Rates

7. Conclusion

Appendices 
1. Origin and Evolution of Administrative Monopoly in the Salt Industry

1.1. Evolution of the salt industry

1.2. Legal bases and related problems

2. Organizational Structure

3. Iodine Addition of Salt and Controlled Monopoly Prices

3.1. Monopoly prices for edible salt

3.2. More costly because of iodine addition?

3.3. Large number of table salt production enterprises

3.4. Overproduction of table salt

3.5. Iodine addition to table salt: The awards are over but it will not leave the stage

4. Production and Sale of Salt: A Two-Tiered Administrative Monopoly

4.1. Inefficient allocation of resources in the salt industry

4.2. Unjust, and harming private salt enterprises, upstream suppliers, and downstream consumers

4.3. Rent-seeking and driving the supply of illegal table salt

4.4. Income distribution under administrative monopoly A case study of China National Salt Industry Corporation

4.5. Extension of the monopoly power to the downstream industries

5. International Experience

5.1. The US

5.2. Japan

5.3. Comparison of the salt industries of China, the US and Japan

6. Reform and Outlook 
Sub-Report 6: Administrative Monopoly in the Sports Industry: A Case Study of the Football Monopoly

1. Position and Power of the Sports Industry Associations in China

1.1. Exclusive position of sports industry associations

1.2. Power of the sports industry associations

1.2.1. Power over managing athlete eligibility and related decisions

1.2.2. Power over discipline and punishments

1.2.3. Power over organizing and managing sports events

1.2.4. Ownership and rights to profit from league games

2. Dominant Position of Sports Industry Associations

3. Harm of the Administrative Monopoly in the Sports Industry

3.1. Infringement of rights and curbing the enthusiasm of league investors

3.2. Harming the quality of league games and obstructing long-term development

3.3. Over-centralization of power leads to rent-seeking and rampant corruption

4. Solutions

Bibliography

Index 
This page intentionally left blank 


\section{Abstract}

In recent years, the development and the strengthening of the market economy in China has encountered severe obstacles, with one of the major reasons being administrative monopolies. Some enterprises, especially large-scale state-owned enterprises (SOEs), have obtained preferential market conditions and artificial advantages in competition. Through the strong support and active cooperation of administrative departments, they have gained different levels of dominance over certain markets. This phenomenon not only compromises sufficient competition, but also undermines the fairness of competition.

By utilizing the administrative monopolies granted through government action, monopoly enterprises have not only damaged economic efficiency and social justice, but also raked in substantial profits on paper. This model of profiting without exhaustive innovation and operation has encouraged blind pursuit for "image," indulgence in position-related consumption, and company welfare and bonuses in monopoly enterprises, which resulted in tremendous waste of resources and social injustice. It also leads to more effective melon-cutting coalitions within interest groups, and stronger intention and motivation to maintain, enhance, and expand administrative monopolies.

The two-fold damage to both economic efficiency and social justice has aroused harsh public criticism of administrative monopolies. Therefore, the investigation and analysis of administrative monopolies is of both strong theoretical value and immediate practical use. 
This page intentionally left blank 


\section{Introduction}

- An "administrative monopoly" is a business monopoly granted by the administrative departments of the government to business agents enterprises or profit-making administrative entities. These monopolies are often granted through the issuance of administrative documents such as regulations, statutes, or guidelines. Administrative monopolies are often characterized by barriers to market entry and price regulations that are issued by administrative departments, establishing stronger or weaker economic monopolies.

- Granting monopoly powers to an enterprise is an important economic decision that represents a shift in the basic economic system (the "socialist market economy"). Under the Law of Legislation, monopolies shall be established by the legislature. According to the principle of law reservation, monopolies established without the approval of the legislature pose great constraints to potential competitors' economic freedom and consumers' freedom of choice. In practice, most administrative monopolies in China are established by formal regulations issued by administrative departments, regulations that the departments themselves authorize. The monopoly powers established by the administrative bodies are unconstitutional and, therefore, illegal.

- Broadly speaking, administrative departments abuse their authority over drafting legislative acts to establish monopoly powers in favor of certain enterprises. This is made possible by a weak legislature, granting these departments their own kind of "administrative monopoly" in the regulatory process. Since the beginning of reform and opening up, China's constitution has been amended several times. There have been great changes made to its fundamental principles, such as 
the introduction of the "socialist market economy," and the guiding principle that "the state encourages, supports and guides the development of the non-public economy." Laws that allow for the creation of administrative monopolies are incompatible with China's constitution.

- Almost all of the main industries subject to administrative monopoly that are discussed in this study evolved out of the completely planned economy. After years of reform to the fiscal system, the central government's main sources of revenue come from taxable income. The central government has incentives to push forward reforms for stateowned enterprises (SOEs), but no incentives to break the monopolies held by these enterprises. On the contrary, granting administrative monopolies as preferential policies to SOEs could be a way to reduce the financial burden on SOEs.

- With the success of China's economic reforms, huge domestic markets have emerged, which in turn highlighted the value of monopolies over these markets. Because the enterprises with monopoly powers do not need to hand over their profits, and there are no ceilings on the level of wages and bonuses, the enterprises keep all the profit derived from the existence of administrative monopolies. As interest groups, they have a strong incentive to attempt an expansion of their administrative monopolies.

- "In-house lobbying" refers to the lobbying of administrative officials done by high-level management at SOEs in order to secure administrative monopolies. One reason for this is the revolving door linking administrators and SOE managers, with SOE managers frequently serving stints in administrative positions and vice versa. This is an indirect yet important indicator of administrative monopolization, and this phenomenon appeared in several industries dealt with in this book.

- "In-house lobbying" works because of the existence of "departmental legislation," the manipulation or creation of legislation by government administrators. "Departmental legislation" exists because of the lack of sufficient supervision over administrative departments in the current political structure, leading to an abuse of power that both directly and indirectly affects legislation. Broadly speaking, "departmental legislation" also refers to the fact that in carrying out administrative duties, departments are in effect creating or amending legislation. 
- Administrative monopolies are created by setting barriers to entering an industry and by regulating prices. Price regulations can be further subdivided into (1) regulations over sales prices by monopolists; and (2) regulations over purchase prices for monopolists. The holders of administrative monopolies can, therefore, obtain resources and other inputs at large discounts or even for free.

- As long as there are institutional barriers to entry, even if other market conditions allow for fair competition, under a certain level of demand, administrative monopolies can also lead to high prices, low production, and welfare losses.

- When barriers to entry drive up prices, they unfairly convert consumer surplus into corporate profits, and in the process further distort income distribution. If the resources that become monopoly profits were used in exchanges dictated by the market, they would go toward the creation of other goods and services. The value of these goods and services (with consumer surplus added in) is the opportunity loss caused by administrative monopolies, along with the social welfare losses from distortions to income distribution.

- Regulation over purchase prices (with factor prices being low or zero) is a serious distortion of income distribution. It unfairly transfers huge amounts of wealth originally belonging to the state or other economic agents to SOEs. We assume that the rents for resources not paid or underpaid for by monopoly enterprises are used to occupy other production factors (such as labor, land, and capital), and that they could be put to more productive use if activities were determined by market forces. The value of such products (with consumer surplus added in) is the opportunity cost caused by the distortion of distribution. In the end, these lead to a decrease in aggregate social welfare.

- Administrative monopolies transfer wealth, in the form of money, from consumers to the companies that enjoy a monopoly, including their management and staff. These companies do not use these monetary resources to produce the corresponding amount of goods or services. From a macro social perspective, there now exists a greater supply of money chasing a relatively low amount of goods, a process that inevitably leads to inflation.

- In recent years, adjusting the deposit reserve requirements instead of interest rates has become the primary means of implementing monetary 
policy. The deposit reserve requirement is frequently adjusted, changing up to ten times a year. The total range of adjustments has been $14 \%$, with the highest rate being $21.5 \%$. From the perspective of banks, adjusting the deposit reserve requirements and adjusting interest rates are very different. This is particularly true when implementing tightening policies where raising the deposit reserve requirements allows banks to avoid the huge costs of raising interest rates.

- Given the government's central role in the creation of administrative monopolies, the losses generated are three-fold. Not only do administrative monopolies lower economic efficiency and violate principles of social justice, but in the formation, maintenance, and strengthening of administrative monopolies, the credibility and authority of the administrators themselves is seriously weakened. This means that SOEs and the control they have over the national economy does not constitute the often-touted "basis of rule" for the government; it is instead a threat to that very rule.

- Following is a figure showing welfare loss and distribution distortions caused by administrative monopoly:

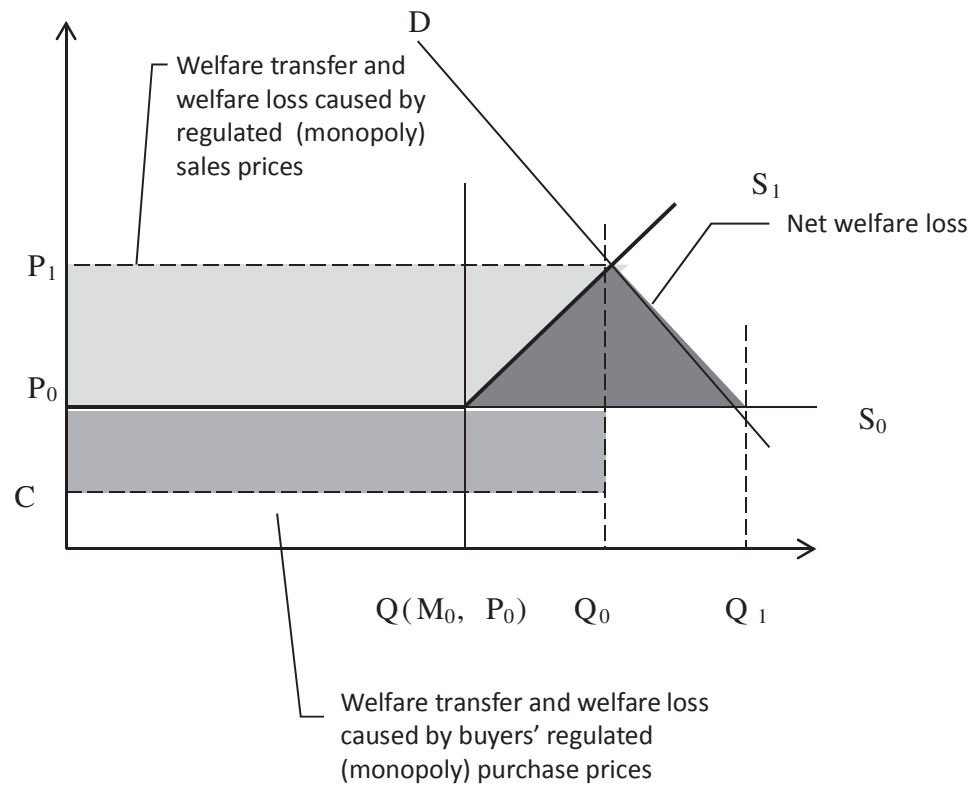

An Illustration of Welfare Losses and Distribution Distortions caused by Administrative Monopoly. 
The dark grey triangle in the figure is the net loss of social welfare caused by administrative monopolies; we call it "Social Welfare Loss I." The light grey part in the figure is distribution distortion caused by monopoly (regulated) sales prices; we call it "Social Welfare Loss II." The grey part in the figure is the distribution distortion caused by buyers' monopoly (regulated) purchase prices (with some costs approaching zero); we call it "Social Welfare Loss III."

- Estimation of social welfare loss I: The net social welfare losses caused by the administrative monopoly granted to China Telecom, China Mobile, and China Unicom from 2003-2010 totaled approximately RMB 84.6 billion. Total social welfare losses throughout the telecom industry during the same period were up to RMB 441.7 billion, and the corresponding losses in the oil industry total around RMB 1.309 trillion.

- Estimation of social welfare loss II (i.e. the profits derived from monopoly pricing): The annual rents accrued from administrative monopolies in the telecommunications industry average approximately RMB 31.3 billion per year. This amount is equal to the decrease in consumer surplus. The monopoly profits brought about by high prices in the oil industry total around RMB 437.8 billion. The monopoly profits in the salt industry are as high as RMB 17.7 billion per year. These are direct losses for consumers and also amount to social welfare losses.

- Estimation of social welfare loss III: From 2001 to 2010, PetroChina underpaid by RMB 166.8 billion on rental costs for industrial-use land. On land used for gas stations, PetroChina and Sinopec collectively underpaid by RMB 176.5 billion, and the two underpaid RMB 289.8 billion in royalties. Collectively, the Big Three in the oil industry underpaid on finance costs by RMB 224.5 billion, with all of these underpayments contributing to social welfare losses.

- In most market economies, the average difference between deposit rates and interest rates on loans is around 1-2\%. In China, the difference between one-year loan rates and deposit rates has averaged $3.06 \%$ in recent years. This is achieved by pushing deposit rates down to $1.5 \%$. With total national deposits averaging RMB 77.156 trillion in 2011, estimates of the losses to individuals and institutions total RMB 1.157 trillion, equal to $2.6 \%$ of GDP in that year. 
- The persistent difficulty in buying train tickets in China indicates a general supply shortage for ordinary (non-high-speed) tickets. Judging from the constant traffic jams on the Beijing-Tibet Expressway (some reaching $100 \mathrm{~km}$ and lasting for ten days) and the Qingdao-Yinchuan Expressway caused by a glut of freight trucks, there appears to be a general shortage of railway freight capacity. At the same time, the already constructed high-speed railway lines are largely underutilized relative to optimal passenger levels. This suggests a severe misallocation of investment between high-speed and conventional railways.

- Reports estimate that in order for the utility-to-cost ratio of high-speed railway to equal that of regular railways, the high-speed line requires 129 daily departures. As we know, the busiest Beijing-Shanghai highspeed line has only 50-90 daily departures. This means that the decrease in construction of normal railways in favor of high-speed lines will lead to net social welfare losses. In accordance with relevant data, the welfare losses caused by the misallocated resources between high-speed and conventional railway is approximately RMB 53.3 billion per year.

- The net social welfare losses due to administrative monopolies in 2010 (including losses from misallocated railway spending) were equal to RMB 1.91 trillion. The combined losses due to monopoly sales pricing (social welfare loss II) and monopoly purchase prices on inputs equal RMB 1.62 trillion. Social welfare loss II is equal to the quantity of money that lacks corresponding goods and services, and thus inevitably brings about inflation pressure. Specifically, it will cause inflation to rise by $2.4 \%$, equivalent to $78.7 \%$ of the rise in the retail goods price index for that year.

- In terms of adjusting deposit reserve requirements as an alternative to adjusting interest rates, we look at the June 20, 2011 decision by the People's Bank of China (PBOC) to raise deposit reserve requirements by $0.5 \%$. The equivalent interest rate change would be $0.375 \%$, but the decision to adjust deposit reserve requirements saved banks RMB 321.7 billion in interest payments.

- The PBOC raised reserve requirements six times in 2011, each time by $0.5 \%$. That is, equivalent to reducing the interest payments of banks and their main borrowers by RMB 1.562 trillion. 
- Although there are some shortcomings in the current Anti-Unfair Competition Law (反不正当竞争法) and Anti-Monopoly Law (反垄 断法), the laws do articulate legal constraints on the exercise of administrative monopolies. The monopoly behaviors defined in the AntiMonopoly Law include achieving monopoly agreements between business agents, abusing monopoly positions, and concentrating firms for purpose of limiting or excluding competitors. There is even a particular chapter in the law to forbid "the abuse of administrative powers to exclude and to limit competition."

- Administrative departments should avoid legislating through the preparation of drafts, especially when drafts of bills pertain to specific monopolies. At a bare minimum, these types of legislation should be drafted by neutral agents authorized by the legislature. Moreover, the legislature should organize committees of experts to review drafts for the establishment of monopolies in specific industries. Furthermore, the establishment of a specific monopoly should be treated as an isolated event. The legislature should avoid the creation of monopolies by reference to broad categories such as the often-cited "economic lifeline of the country."

- Administrative departments do not have the power to establish specific monopolies. Any monopoly established by administrative departments through regulations or statutes is illegal. Rules should be established that exclude related administrative departments from the drafting of "implementation details" or "regulations." Alternatively, the review of drafted "implementation rules" of specific laws could be strengthened to prevent the adding of articles related to the establishment or expansion of specific monopolies.

- The power of administrative departments to regulate prices should only come with authorization by the legislature. When an administrative department uses its price-regulating power, it should abide by the Price Law (价格法), and must first go through fair hearings. In particular, it should differentiate between the adjustment of interest rates by the PBOC to implement monetary policy and the interest rates of commercial banks. The PBOC should avoid the regulation of commercial bank interest rates in the name of implementing monetary policy.

- The constitutional powers to govern the state-owned sector of the public economy could be used to more effectively monitor and 
constrain the management of SOEs. Because public resources and assets should be owned by all people, the supervision of these resources and assets should be strengthened. It must be assured that these assets do not flow into the hands of the managers who operate SOEs. Given the difficulties in effective public oversight of these resources and assets, this responsibility for supervision should be emphasized in the constitution, and established by corresponding institutions and rules in laws.

- The Standing Committee of the National People's Congress, as a specialized constitutional supervisory authority, can and should review and terminate unconstitutionally established administrative monopolies. At the same time, based on the provisions of existing constitutional law, the Law of Legislation (立法法) empowers authorities (mainly the Standing Committee of the National People's Congress and the State Council) to terminate or revoke existing administrative documents that establish administrative monopolies.

- Proposals for judicial reforms to break administrative monopolies include:

First, allow plaintiffs (not limited just to companies) to directly sue the companies suspected of holding an administrative monopoly. In addition, expand the rights of the plaintiff to include not merely suing for civil liabilities, but also requesting the court to review the legality of the monopoly itself.

Second, amend the relevant legislation so that courts have substantive power to review the cases of administrative monopoly and to dispose of the monopoly status.

Third, reinvigorate existing anti-trust administrative enforcement mechanisms. The keys are to consolidate institutions and functions, improve authority (for example, not relying on "recommendations to the superior authority"), and strengthen the legitimacy of the process by ensuring a fair, transparent, and participatory process, rather than relying on internal operations.

Fourth, establish a system for publicly prosecuting administrative monopolies. 
- Below are listed recommendations for breaking administrative monopolies at the administrative level:

First, directly encourage enterprises, including private enterprises and SOEs, to enter the sectors where there is an absence of legal provisions of monopolies. For instance, in the oil industry there are only administrative documents, but no legal restrictions to entry. Any administrative departments that impede enterprises from entering these fields should be subject to administrative penalties.

Second, abolish and prohibit administrative departments from granting monopolies to themselves (or industrial associations controlled by them) by way of executive orders.

Third, require the Ministry of Finance, the Ministry of Land Resource, and other related departments to set up specialized agencies to verify the number of public natural resources (including land and mining licenses) occupied by enterprises, and charge rents at market prices to companies that utilize these resources.

Fourth, require the State-owned Assets Supervision and Administration Commission (SASAC) of the State Council to set a reasonable wage ceiling on SOE employees based on average wages in society, and punish those who earn above these limits.

Fifth, request that the Ministry of Finance establish specialized agencies to monitor SOEs (particularly central SOEs), give recommendations to the State Council on the distribution of profits, strictly implement the remittance of profits, and supervise the use of profits reinvested in the companies.

Lastly, in the long run, promote the withdrawal of SOEs from profitmaking areas.

Note:

- In this book, the word "monopoly" will be used to refer to a range of monopoly, duopoly and oligopoly dynamics, with the scope of market concentration ranging along that spectrum.

- In this book, all Chinese names will be written according to the Chinese convention of placing the surname before the given name. 